\title{
Kebijakan Developmental State Indonesia dalam Perdagangan Komoditas Hortikultura, Hewan, dan Produk Hewan
}

\author{
Septian Nur Yekti \\ Universitas Muhammadiyah Malang
}

\begin{abstract}
Indonesia insists to defend its regulation on trade of horticulture, animals, and animal products after its loss on New Zaeland's indictment in Dispute Settlement Body (DSB) of World Trade Organization (WTO). Indonesia appealed the DSB decision, despite previous findings in DSB panel which reports that Indonesia's regulations contains trade restriction and various trade barriers. This paper analyzes the reason why Indonesia appealed the DSB Panel decision, despite the fact that Indonesia violates WTO principles which lead to free trade barriers. This paper uses law perspective to find out whether Indonesia really violates the law or not. Besides, this paper also uses developmental state theory to analyze the case. The theory takes root in the merchantilism which emphasizes on export, domestic production, and national welfare. Developmental state's position lies between liberalization and centered-plan policy which means that the country that applying this policy joins the globalization and plays its role in international order to reach national welfare.
\end{abstract}

Keywords: developmental state, trade dispute settlement, trade restriction

\begin{abstract}
Abstrak
Indonesia mempertahankan aturan perdagangan komoditas hortikutltura, hewan, dan produk hewan setelah kekalahannya atas tuntutan Selandia Baru di Dispute Settlement Body (DSB) World Trade Organization (WTO). Indonesia mengajukan banding terlepas dari buktibukti yang ditunjukkan dalam laporan panel DSB. Tulisan ini menganalisa alasan Indonesia mengajukan banding meskipun bukti-bukti dari sisi hukum menunjukkan bahwa Indonesia melanggar prinsip-prinsip WTO yang berujung pada pembatasan dan hambatan perdagangan bebas. Tulisan ini menggunakan tinjauan hukum untuk mengetahui apakah Indonesia benar-benar melanggar kesepakatan WTO. Selain itu, tulisan ini juga menggunakan Teori Developmental State untuk menganalisa kasus. Developmental state berakar dari merkantilisme yang menekankan ekspor, produksi dalam negeri, dan kesejahteraan nasional. Developmental state berada pada posisi di antara liberalisme dan ekonomi terpusat yang berarti bahwa negara yang menerapkan developmental state turut serta dalam globalisasi dan memainkan perannya di sistem internasional untuk mencapai kesejahteraan nasional.
\end{abstract}

Kata-kata kunci: developmental state, pembatasan perdagangan, penyelesaian sengketa perdagangan 


\section{Pendahuluan}

Diwadahinya aturan perdagangan bebas antarnegara General Agreement on Tariff and Trade (GATT) ke dalam Organisasi Perdagangan Dunia (WTO) pada tahun 1995 menjadi awal perkembangan pesat perdagangan bebas antarnegara. Organisasi ini tidak hanya menyediakan aturan yang mengikat tentang liberalisasi perdagangan barang dan jasa, namun juga menambahkan aturan pada liberalisasi modal dan aturan tentang perlindungan hak kekayaan intelektual. Peningkatan perdagangan bebas yang dimaksud adalah peningkatan dalam volume perdagangan internasional pasca berdirinya WTO dan peningkatan jumlah negara anggota. Dapat diambil contoh, nilai perdagangan barang pada tahun 2005 mencapai US\$11.000 miliar. Nilai ini terus mencapai peningkatan sampai pada tahun 2008 yang mencapai US\$16.000 miliar, kemudian mengalami penurunan menjadi US\$12.000 miliar pada tahun 2009. Nilai perdagangan internasional terus mengalami peningkatan kembali dari tahun ke tahun hingga mencapai US\$18.500 miliar pada tahun 2014 (World Trade Statistic Review, 2016). Keanggotaan WTO mulai Juli 2016 berjumlah 164 negara (WTO, 2017). Pesatnya peningkatan tersebut menunjukkan antusiasme negara-negara di dunia untuk turut serta dalam perdagangan bebas guna mengambil keuntungan dari sistem tersebut.

Perdagangan bebas dinilai dapat memberikan keuntungan bagi penganutnya, sebagaimana yang disebutkan oleh WTO bahwa tujuan dibentuknya organisasi ini adalah: 1) mencapai perdagangan internasional yang stabil dan menghindari kebijakan-kebijakan dan praktik-praktik perdagangan nasional yang merugikan negara lainnya; 2) meningkatkan volume perdagangan dunia dengan menciptakan perdagangan yang menarik dan menguntungkan bagi pembangunan ekonomi semua negara; 3) meningkatkan standar hidup manusia; 4) meningkatkan lapangan tenaga kerja; 5) mengembangkan sistem perdagangan multilateral, bukan sepihak suatu negara tertentuyang akan mengimplementasikan kebijakan perdagangan terbuka yang bermanfaat bagi negara-negara; 6) meningkatkan pemanfaatan sumber-sumber kekayaan dunia dan meningkatkan produk serta transaksi jual beli barang (Adolf, 2005: 21-22). Dengan demikian, dipercaya bahwa dengan mengikuti aturan main WTO sebagai rezim perdagangan bebas, negara-negara anggota dapat mencapai keuntungan ekonomi maksimal.

Aturan main WTO secara umum dapat dilihat dari tiga prinsip utamanya. Pertama yaitu mostfavoured nations atau tidak diperbolehkannya negara anggota WTO untuk memberikan perlakuan yang lebih istimewa atau berbeda kepada masing-masing negara anggota lainnya. Dalam hal ini, perlakuan dalam perdagangan yang diberikan oleh suatu negara anggota harus sama terhadap semua negara anggota. Prinsip kedua adalah 
national treatment yang berarti bahwa negara anggota tidak diperkenankan memberikan perlakuan berbeda antara produk negara anggota lain dengan produk yang sama atau serupa yang diproduksi di dalam negeri. Prinsip ketiga adalah transparansi yang berarti bahwa semua aturan dalam negeri terkait perdagangan negara anggota harus dapat diakses dan dievaluasi, baik oleh WTO maupun negara anggota yang lain agar tetap berjalan sesuai dengan prinsip-prinsip perdagangan bebas. Pada intinya, prinsip-prinsip tersebut menjamin agar tidak ada lagi hambatan dalam perdagangan bebas, baik hambatan tariff dan hambatan non-tariff yang diakibatkan oleh kebijakan atau aturan negara anggota.

Untuk menjamin penghilangan hambatan tariff dan non-tariff, WTO membuat aturan detail yang tertuang dalam pasal-pasal General Agreement on Tariff and Trade (GATT) untuk mengatur perdagangan barang, General Agreement on Tariff on Services (GATS) untuk perdagangan jasa, Trade Related to Investment Measures (TRIMs) untuk aliran modal, dan Trade Related to Intellectual Property Rights (TRIPs) untuk perlindungan hak kekayaan intelektual dalam perdagangan bebas. Negara-negara anggota wajib memenuhi ketentuan pasal-pasal aturan tersebut dalam menjalankan perdagangan internasional. Negara yang tidak memenuhi ketentuan dalam aturan WTO dianggap melanggar dan dalam sebagian besar kasus akan menimbulkan kerugian bagi negara mitra dagang. Dalam kasus pelanggaran ini, negara yang dirugikan berhak untuk menuntut negara pelanggar ke Dispute Settlement Body WTO yang merupakan badan yang menangani penyelesaian sengketa perdagangan internasional negaranegara anggotanya.

Tulisan ini akan membahas mengenai sengketa perdagangan hortikultura, hewan, dan produk hewan antara Indonesia dengan Selandia Baru. Pada tahun 2014, Selandia Baru melaporkan Indonesia ke WTO atas dugaan pelanggaran aturan perdagangan berupa penetapan hambatan non-tariff pada produk-produk impor hortikultura, hewan, dan produk hewan. Pelanggaran ini merugikan Selandia Baru sebagai negara penghasil komoditas tersebut. Pemberlakuan aturan perdagangan komoditas di atas oleh Indonesia berdampak pada penurunan $80 \%$ perdagangan hortikiltura, hewan, dan produk hewan Selandia Baru. Kerugian ditaksir mencapai US\$1 miliar karena Indonesia merupakan pasar utama komoditas tersebut (New Zaeland First Written Submission to WTO, 2015). Dampak kerugian yang diakibatkan oleh aturan perdagangan Indonesia ini juga dirasakan oleh Amerika Serikat. Terkait hal tersebut, sebagai negara yang menderita kerugian akibat aturan perdagangan yang berlaku, Selandia Baru bersama dengan Amerika Serikat mengajukan tuntutan terhadap Indonesia.

Setelah proses pengajuan tuntutan oleh kedua negara dan proses penyelesaian sengketa oleh panel di Dispute Settlement Body (DSB), 
diputuskan bahwa Indonesia bersalah karena terbukti melanggar aturan WTO dengan menerapkan hambatan perdagangan non-tariff yang merugikan negara anggora lain. Sebagai konsekuensi, Indonesia diminta untuk merubah aturan perdagangannya sehingga tidak lagi memuat hambatan perdagangan. Namun demikian, alih-alih menerima keputusan panelDSB, Indonesia mengajukan banding ke Appellated Body WTO. Dalam hal ini. penulis tertarik untuk menganalisa keputusan Indonesia untuk mempertahankan aturan perdagangannya yang dinilai melanggar aturan perdagangan bebas dengan mengajukan banding setelah kekalahannya di DSB. Sebagai negara anggota rezim perdagangan bebas, Indonesia hendaknya mengikuti semua aturan yang menjamin penghapusan segala hambatan. Lebih lanjut, apabila hambatan perdagangan komoditas hortikultura, hewan, dan produk hewan dihilangkan, keuntungan tidak hanya dirasakan olehnegara mitra pengekspor komoditas tersebut (Selandia Baru dan Amerika Serikat), namun masyarakat Indonesia seperti para importir, pengusaha supermarket, dan masyarakat konsumen komoditas tersebut karena ketersediaan akan melimpah dan harganya yang semakin murah.

Tulisan ini menganalisa apakah keputusan Indonesia didasari oleh tinjauan aturan perdagangan WTO yang dinilai masih membenarkan aturan perdagangan Indonesia atau latar belakang pertimbangan lain. Dengan demikian, pertanyaan yang diajukan dalam tulisan ini adalah mengapa Indonesia mengajukan banding ke Appellate Body WTO setelah kekalahannya atas tuntutan Selandia Baru terkait aturan perdagangan hortikultura, hewan, dan produk hewan di DSB.

\section{Kerangka Pemikiran}

Dalam menganalisa studi kasus dalam tulisan ini, penulis melihat dari tinjauan hukum aturan GATT. Tinjauan hukum ini dimaksudkan untuk mencari tahu pertimbangan Indonesia dalam mengajukan banding dari sisi hukum. Dalam hal ini akan dilihat apakah terdapat pasal-pasal dalam GATT yang dapat ditafsirkan memperbolehkan aturan perdagangan yang diterapkan Indonesia terkait perdagangan hortikultura, hewan, dan produk hewan. Selain itu, tinjauan hukum ini juga dimaksudkan untuk memaparkan pasal-pasal GATT yang dinilai dilanggar oleh Indonesia sesuai dengan tuntutan Selandia Baru. Berdasarkan tuntutannya, Selandia baru menilai Indonesia melanggar GATT 1994 Pasal III:4, X:1, XI:1, Kesepakatan Pertanian Pasal 4.2, Kesepakatan Izin Impor Pasal 1.2, 1.5, 1.6, 2.2, 3.2, 3.3, 5.1, 5.2, dan Kesepakatan Inspeksi Sebelum Pengiriman Pasal 2.1, 2.15.

Lebih lanjut, penulis menggunakan teori developmental state. Teori ini berakar dari merkantilisme yang menekankan intervensi negara dalam ekonomi (Johnson, 1982). Asumsi dasar merkantilisme secara lebih detail 
adalah pertama, negara hanya fokus pada kebijakan ekonomi. Dalam hal ini, negara berupaya mendorong pertumbuhan ekonomi, produktivitas industri, dan daya saing global. Selain itu, negara juga mendorong produksi, bukan konsumsi. Kedua, negara aktif mengintervensi pasar. Pasar cenderung mengalami kegagalansehingga harus diintervensi. Intervensi juga dilakukan untuk menghindari kompetisi eksesif. Ketiga, negara dianggap sebagai birokrasi yang rasional, pintar, dan kompeten. Keempat, birokrasi harus diinsulasi dari tekanan politik. Yang terakhir, negara menerapkan forced saving.

Negara-negara yang menerapkan developmental state mendesain jalan pembangunan yang menerapkan intervensi dalam pasar terbuka liberal. Cara ini menjadi bentuk pembangunan yang pesat di Asia Timur atau kemudian menjadi model negara kesejahteraan kapitalis di Eropa (Bolesta, 2007). Negara yang menerapkan developmental state menerapkan sistem yang memiliki kemampuan pasar untuk membangun sosial ekonomi secara cepat dan stabilitas kesejahteraan sosialis.

Menurut Loriaux, developmental state adalah bentuk dari ambisi normatif atau moral untuk menggunakan kekuatan intervensi negara untuk mengarahkan investasi pada jalan yang mempromosikan visi solidaritas tertentu dari ekonomi nasional (Lariaux dalam Woo-Cumings, 1999: 24). Ha-Joon Chang menggarisbawahi bahwa pembangunan ekonomi mensyaratkan negara yang dapat membuat dan mengatur ekonomi dan hubungan politik yang dapat mendukung industrialisasi berkelanjutan atau lebih singkatnya suatu negara pembangunan atau developmental state (Chang 1999: 183). Lebih lanjut, Johnson (1999) menyebutkan elemen penting dari developmental state dari perspektif mikro ekonomi, yaitu kerjasama antara bisnis swasta dan pemerintah atau dengan kata lain, sektor privat dan sektor publik. Bisnis swasta menjadi mitra pemerintah dalam upaya pembangunan. Dengan demikian, bisnis swasta yang merupakan bagian penting dari pembangunan negara mencirikan developmental state sebagai kapitalis.

Selain itu, Bolesta (2007) menyatakan bahwa karena ekonomi developmental state cenderung export-driven, negara-negara yang menganutnya harus mengikuti kondisi internasional dan memainkan posisi dan perannya pada ekonomi global. Hal tersebut tidak dapat terwujud tanpa adanya negara yang kuat, mampu secara hukum untuk mempengaruhi arah pembangunan. Dalam semua kasus developmental state, negara-negara tidak mengakumulasi kekayaan untuk dihabiskan, namun untuk menambah pendapatan. Selain itu, posisi developmental state yang berada di antara ekonomi neo-liberal dan intervensionis dapat dilihat dari perspektif global. Global ekonomi bukan berarti liberal. Merujuk dari argumen Joseph Stiglitz dan Alexander Hamilton (dalam Woo-Cumings, 
1999:5), perlu diingat bahwa masih akan selalu ada hambatan perdagangan, itulah mengapa selalu ada negosiasi di WTO, sebagaimana tekanan yang kuat dari pemerintah yang memiliki perekonomian kuat dan korporasi internasional yang mempengaruhi harga barang-barang dengan mengikuti kebijakan-kebijakan tertentu (Chang 1999: 197).

Selain itu, Christopher M. Dent (2003) memandang developmental state dari sisi keamanan ekonomi. Menurut Dent, developmental state merupakan usaha untuk melindungi integritas struktural dan kemampuan mencapai kesejahteraan serta kepentingan entitas politik ekonomi dalam konteks berbagai resiko eksternal dan ancaman dihadapinya (Dent, 2003: 253). Aspek integritas struktural terkait dengan pengelolaan konstruksi ekonomi internal dalam interaksinya dalam ekonomi global dan kemampuannya untuk memenuhi permintaan dasar agen-agen ekonomi yang berada di dalamnya. Aspek kapabilitas pencapaian kesejahteraan memperluas batasan konvensional konsep keamanan ekonomi melampaui perhatian umum untuk meminimalisir kerentanan ekonomi secara langsung dan seketika. Secara garis besar, keamanan ekonomi dan aspek-aspeknya dapat dilihat pada gambar berikut:

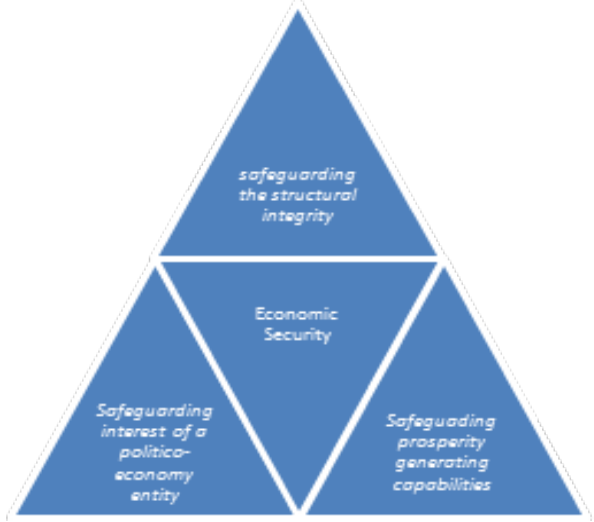

\section{Gambar 1: Keamanan ekonomi dan aspek-aspeknya}

Lebih lanjut, Linda Weiss dalam States in the Global Economy (2003) menyebutkan dua macam kebijakan pemerintah dalam menghadapi globalisasi, yaitu kebijakan buruk dan kebijakan baik. Kebijakan buruk di bawah globalisasi meliputi pertama, tekanan keterbukaan struktural yang harus bekerja dan memberikan efek pada kebijakan yang mengikuti jalan: keterbukaan ekonomi kapitalisme 'entry' dan 'exit' yang berarti bahwa investor dan perusahaan asing dapat dengan mudah masuk dan keluar. Kedua, karena hambatan perdagangan, investasi, dan finansial dihilangkan, pemerintah bersaing untuk menarik dan mendapatkan modal asing. Mereka 
harus menciptakan kebijakan yang memihak kepentingan perusahaan multinasional (PMN) dan pasar finansial dengan mengijinkan investor yang mobilitasnya tinggi untuk memiliki opsi exit atau keluar. Kebijakan ini menjadikan kondisi tersebut sebagai pertimbangan untuk memperendah pajak dan mengabaikan masalah lingkungan. Hasilnya, keterbukaan finansial dan mobilitas perusahaan diperkirakan menekan kebijakan fiskal dan sosial, memaksa pengurangan kebijakan kesejahteraan, pengurangan pajak perusahaan, dan memindahkan beban pajak dari pemilik modal ke buruh. Efek ini populer disebut sebagai 'race to the bottom'.

Kebijakan baik dalam globalisasi meliputi pertimbangan mengenai keterbukaan yang kuat dalam pasar. Dunia memiliki kecenderungan untuk menambah ketidakamanan antara segmen yang luas dalam populasi yang akan memicu permintaan untuk perlindungan sosial. Dengan demikian, daripada menerapkan pemotongan hambatan liberalisme secara umum, pemerintah akan menerapkan insentif politik yang kuat untuk mempertahankan atau meningkatkan kompensasi domestik. Akibat keterbukaan ekonomi yang kuat berkorelasi dengan peningkatan persepsi kerentanan, hal ini memberikan kebangkitan pada ideologi kamitraan sosial dan penyusunan institusi yang melengkapi.

Dalam kasus yang dibahas dalam tulisan ini, Indonesia dinilai menerapkan developmental state dalam menghadapi tuntutan Selandia Baru terkait aturan perdagangan komoditas hortikultura, hewan, dan produk hewan. Indonesia mengikuti rezim perdagangan bebas WTO dan hendaknya mengikuti aturan-aturannya. Namun demikian, Indonesia juga memposisikan diri dan memainkan perannya dalam liberalisasi perdagangan yang diikutinya. Hal tersebut tercermin dalam hambatan perdagangan komoditas tersebut yang dinilai melindungi produsen domestik. Kondisi ini sesuai dengan prinsip-prinsip merkantilisme yang merupakan akar dari developmental state. Indonesia berupaya mencapai keamanan ekonomi terkait komoditas ini, yang mencakup keamanan integritas struktural dan entitas ekonomi yang bermain di dalamnya, serta berupaya melindungi kesejahteraan domestik terkait komoditas tersebut Indonesia juga menerapkan kebijakan yang baik dalam menghadapi globalisasi, yaitu memberikan perlindungan terhadap masyarakat yang rentan akibat semakin hilangnya hambatan perdagangan dan keterbukaan pasar. Hal ini dilakukan untuk menghindari kondisi race to the bottom. Dalam hal kewajibannya untuk mengikuti aturan internasional, Indonesia memainkan strategi merubah aturan perdagangan yang dipersengketakan sebelum naik banding ke appellate agar sedikit menyesuaikan aturan-aturan GATT. Lebih lanjut, strategi ini akan dibicarakan pada bagian pembahasan. 


\section{Proses Penyelesaian Sengketa Perdagangan Indonesia dan Selandia Baru di Dispute Settlement Body (DSB)}

Di bawah rezim perdagangan bebas WTO, sengketa muncul ketika negara anggota menganggap bahwa negara anggota lain melanggar kesepakatan atau komitmen yang telah dibuat di WTO. Penulis dari kesepakatan tersebut adalah negara-negara anggota melalui negosiasi. Dengan demikian, tanggung jawab untuk menyelesaikan sengketa juga terletak pada negara-negara anggota melalui Dispute Settlement Body (DSB). Dispute Settlement Body (DSB) merupakan pihak ketiga. Semua anggota yang bersengketa dan belum mendapatkan penyelesaian secara bilateral dapat memanfaatkan panel DSB. Peran DSBdi WTO memiliki dimensi hukum internasional. Syarat, metode, dan aturan DSM terdapat pada pasal XXII and XXIII dari GATT 1994. Orientasi sistem DSM dalam kasus perdagangan internasional berbasis pada aturan-aturan WTO.

Dalam menyelesaikan sengketa, DSB membentuk panel yang bertugas membicarakan sengketa, menilai fakta, hingga memutuskan hasil penyelesaian sengketa. Panel serupa dengan pengadilan, namun tidak seperti pengadilan biasa, panelis biasanya dipilih melalui konsultasi dengan negara-negara yang sedang bersengketa. Hanya apabila kedua belah pihak tidak mencapai persetujuan, direktur jenderal WTO menunjuk para panelis. Panel terdiri dari tiga hingga lima ahli dari negara-negara yang berbeda yang meneliti bukti-bukti dan memutuskan siapa yang benar dan salah. Laporan panel kemudian diserahkan kepada DSB yang hanya dapat menolak laporan panel tersebut dengan konsensus. Panelis pada masing-masing kasus dapat dipilih dari daftar permanen dari kandidatkandidat yang memiliki kualifikasi yang bagus atau dari kalangan lain. Mereka bekerja berdasarkan kapasitas individu serta tidak diperbolehkan menerima instruksi dari negara manapun. Adapun prosedur penyelesaian sengketa di WTO adalah sebagai berikut: 




Gambar 2: Prosedur penyelesaian sengketa di DSB

Dalam kasus yang dibahas pada tulisan ini, Selandia Baru menganggap aturan perdagangan komoditas hortikultura, hewan, dan produk hewan yang ditetapkan oleh Indonesia melanggar kesepakatan GATT dan menimbulkan hambatan perdagangan. Secara garis besar, aturan yang melanggar tersebut adalah pembatasan impor dengan menetapkan aturan bahwa impor hanya dilakukan bila produksi dalam negeri tidak cukup memenuhi permintaan pasar, pembatasan pihak importir dengan syarat-syarat tertentu, dan pembatasan distribusi produk impor pada pasar tertentu saja di Indonesia. Secara detail, kesepakatan WTO yang dilanggar oleh aturan dagang Indonesia akan dibicarakan pada bagian pembahasan selanjutnya.

Akibat pelanggaran oleh Indonesia tersebut, Selandia Baru mengalami kerugian karena ia merupakan penghasil daging sapi dan Indonesia merupakan pasar utamanya. Terkait dengan kerugian tersebut, Selandia Baru mengajukan permintaan konsultasi dengan Indonesia pada WTO. Surat permohonan tersebut diajukan oleh Selandia Baru pada $8 \mathrm{Mei}$ 2014. Permohonan ini diajukan Selandia Baru bersama dengan Amerika Serikat yang mulai bergabung dalam konsultasi pada 20 Mei 2014 karena memiliki kerugian yang sama akibat pelanggaran Indonesia. Tidak hanya Amerika Serikat, beberapa negara juga bergabung dalam konsultasi, yaitu Kanada, Taiwan, Uni Eropa, dan Australia. Setelah itu, Indonesia 
menginformasikan pada DSB bahwa ia menerima permintaan konsultasi dari negara-negara tersebut.

Karena tidak dicapai kesepakatan dalam konsultasi, pada 18 Maret 2015, Selandia Baru mengajukan permintaan untuk membentuk panel. Pada pertemuan tanggal 20 Mei 2015, DSB membentuk panel tunggal berdasarkan Pasal 9.1 Dispute Settlement Understanding (DSU) untuk menyelidiki sengketa. Negara-negara pihak ketiga adalah Australia, Brazil, Kanada, Tiongkok, Uni Eropa, India, Jepang, Norwegia, Paraguay, Singapura, Taiwan, Argentina, Korea, dan Thailand.

Pada tanggal 28 September 2015, Selandia Baru dan Amerika Serikat meminta Direktur Jenderal untuk menyusun panel. Pada 8 Oktober 2015, Direktur Jenderal membentuk panel. Pada 22 Desember 2016, laporan hasil penyelidikan dan pembahasan panel diserahkan pada anggota WTO.

Panel menemukan bahwa semua 18 tindakan yang sedang dipermasalahkan adalah larangan impor atau pembatasan yang memiliki efek pembatasan impor dan oleh karena itu tidak sesuai dengan Pasal XI: 1 dari GATT 1994. Panel menolak pembelaan Indonesia berdasarkan Pasal XX GATT 1994 karena Indonesia tidak dapat membuktikan bahwa aturannya dibenarkan berdasarkan ketentuan tersebut. Panel juga menolak acuan Indonesia terhadap Pasal XI: 2 (c) (ii) dari GATT 1994 karena pengecualian ini tidak dapat dijalankan berdasarkan Pasal 4.2 dari Persetujuan tentang Pertanian.

Pada tanggal 17 Februari 2017, Indonesia menyatakan kepada DSB mengenai keputusannya untuk mengajukan banding ke Appellate Body mengenai temuan hukum dan interpretasi hukum dalam laporan panel.

\section{Tinjauan Hukum Sengketa Perdagangan Indonesia-Selandia Baru}

Secara detail, pengajuan tuntutan dari Selandia Baru terkait aturan perdagangan komoditas hortikultura, hewan, dan produk hewan di Indonesia adalah bahwa Selandia Baru merasa dirugikan atas aturan Indonesia. Sehubungan dengan produk hortikultura, aturan perizinan impor nonotomatis di Indonesia melibatkan setidaknya tiga elemen: 1) penunjukan importir oleh Kementerian Perdagangan sebagai Produsen Importir (PI) atau Importir Terdaftar (RI) untuk produk hortikultura; 2) Rekomendasi Impor Produk Hortikultura (RIPH) dari Kementerian Pertanian; dan 3) Persetujuan Impor dari Kemeterian Perdagangan. Penunjukan PI/RI membatasi produk hortikultura yang dapat diimpor. Bagi persyaratan importir komoditas hewan dan produk hewan, kriteria tambahan adalah bahwa importir harus memenuhi persyaratan importir yang ditetapkan Kemendag. Persetujuan RIPH dan Impor komoditas hortikultura berlaku untuk jangka waktu enam bulan. Sedangkan komoditas hewan dan produk hewan berlaku empat bulan. Permohonan untuk dokumen-dokumen ini 
hanya dapat diajukan dan diterbitkan selama dua periode dalam satu tahun. Persetujuan Impor menentukan antara lain jumlah total dan negara asal produk hortikultura yang dapat diimpor oleh importir selama periode tersebut (Request for Consultation by New Zaeland, 2014).

Aturan izin impor di Indonesia bukan merupakan aturan lisensi otomatis, dan tidak dapat dibenarkan sebagai aturan lisensi nonotomatis yang menerapkan aturan WTO.Peraturan lisensi impor nonotomatis di Indonesia dianggap melarang dan membatasi impor dengan cara berikut: 1) Sehubungan dengan produk hortikultura, sertifikat RIPH tidak mengizinkan impor produk hortikultura segar untuk konsumsi yang telah dipanen lebih dari enam bulan yang lalu; 2) Sehubungan dengan hewan dan produk hewani, setiap produk hewani yang tidak tercantum dalam lampiran peraturan perizinan impor tidak dapat diimpor sama sekali; 3) Sehubungan dengan produk hortikultura, hewan dan produk hewan, importir dapat mengajukan permohonan Persetujuan Impor hanya selama jangka waktu tertentu yaitu beberapa bulan sebelum waktu impor dan setelah diterbitkan. Persetujuan Impor membatasi impor selama periode waktu yang ditentukan untuk mengatur produk dalam jumlah yang ditetapkan, dari negara-negara yang ditetapkan, dan dalam kondisi yang ditetapkan; 4) Importir harus memprediksikan terlebih dahulu jumlah produk yang akan mereka impor selama periode tertentu dan menerapkannya sesuai dengan jumlah tertentu, yang akan dinyatakan dalam Persetujuan Impor mereka yang mencakup jangka waktu tiga atau enam bulan. Importir menghadapi penunjukan mereka sebagai RI/PI yang ditangguhkan atau dicabut jika jumlah sebenarnya yang diimpor kurang dari persentase tertentu dari jumlah yang dinyatakan; 5) Impor produk hortikultura dan hewan serta produk hewani sehubungan dengan jenis penggunaan, penjualan, pembelian, dan/atau distribusi tertentu dilarang atau dibatasi; 6) Impor produk hortikultura, hewan, dan produk hewan dilarang apabila produksi dalam negeri dianggap cukup untuk memenuhi kebutuhan dalam negeri; 7) Impor produk hortikultura tertentu, hewan, dan produk hewani dilarang atau dibatasi bila harga produk tersebut berada di bawah harga referensi tertentu, yang ditetapkan oleh badan di kementerian (baik Tim Pemantau Produk Hortikultura atau Tim Pemantau Harga Daging Sapi) (request for Consultation by New Zaeland, 2014).

Indonesia juga telah mengadopsi langkah-langkah membatasi penjualan internal yang menawarkan jual beli, distribusi, atau penggunaan produk hortikultura yang diimpor; hewan; dan produk hewani;dengan cara yang sesuai dengan perlakuan yang kurang menguntungkan daripada yang diberikan untuk produk dalam negeri sejenis. Hal tersebut misalnya, aturan Indonesia yang membatasi penjualan internal produk hortikultura impor ke distributor, dan membatasi penjualan daging sapi impor untuk 
digunakan hanya di industri dan sektor hotel, restoran, dan katering. Indonesia tidak menerapkan batasan yang sama seperti produk dalam negeri. Hal ini tentu saja berlawanan dengan prinsip national treatment WTO.

Aturan yang diberlakukan Indonesia mencakup persyaratan pemeriksaan preshipment. Persyaratan tersebut mengulangi informasi yang sudah diberikan dalam sertifikat phyto-sanitary sehingga lebih bersifat pembatasan perdagangan. Hal tersebut dapat dilihat pada administrasi kegiatan inspeksi pra-pengiriman yang dibatasi oleh Indonesia ke perusahaan tunggal di Selandia Baru, Bureau Veritas. Indonesia telah gagal untuk memastikan bahwa kegiatan pemeriksaan pra-pengapalan tidak mengakibatkan penundaan yang tidak masuk akal, dilakukan dengan cara yang tidak diskriminatif, dan diterapkan secara setara untuk semua eksportir (Request for Consultation by New Zaeland, 2014).

Sehubungan dengan rezim perizinan impornya, Indonesia juga telah gagal mematuhi kewajiban pemberitahuan berdasarkan Pasal 5 dari Persetujuan Perizinan Impor dan persyaratan publikasi berdasarkan Pasal 3 dari Persetujuan Perizinan Impor.

Instrumen hukum penerapan aturan tersebut oleh Indonesia, meskipun termasuk ke dalamnya, namun tidak terbatas pada instrumen berikut: 1) Undang-Undang Republik Indonesia Nomor 7 Tahun 2014 tentang Perdagangan (Undang-Undang Perdagangan); 2) Undang-Undang Republik Indonesia Nomor 13 Tahun 2010 tentang Hortikultura (Hukum Hortikultura);3) Peraturan Menteri Pertanian Nomor 86/Permentan/OT.140/ 8/2013 tentang Rekomendasi Impor Produk Hortikultura (Peraturan Menteri Pertanian Nomor 86/2013), yang membatalkan dan menggantikan Peraturan MenteriPertanianNomor47/Permentan/OT.140/4/2013tentangRekomendasi Impor Produk Hortikultura (Peraturan Menteri Pertanian Nomor 47/2013), yang mencabut dan menggantikan Peraturan Menteri Pertanian Nomor 60/Permentan/OT.140/9/2012 dan Peraturan Kementan Nomor 60/2012); 4) Peraturan Menteri Perdagangan Nomor 16/M-DAG/PER/4/2013 tentang Ketentuan Impor Produk Hortikultura (Peraturan Menteri Perdagangan Nomor 16/2013), yang membatalkan dan menggantikan Peraturan Menteri Perdagangan Nomor 30/M-DAG/PER/5/2012 tentang Ketentuan Impor Produk Hortikultura (Peraturan Menteri Perdagangan Nomor 30/2012) dan Peraturan Menteri Perdagangan Nomor 60/M-DAG/PER/9/2012 tentang Perubahan Kedua Atas Peraturan Menteri Perdagangan Nomor 30/M-DAG/ PER/5/2012 tentang Ketentuan Impor Produk Hortikultura (Peraturan Perundang-undangan Nomor 60/2012); 5) Peraturan Menteri Perdagangan Nomor 47/M-DAG/PER/8/2013 tentang Perubahan Atas Peraturan Menteri Perdagangan Nomor 16/M-DAG/PER/4/2013 tentang Ketentuan Impor Produk Hortikultura (Peraturan Menteri Perdagangan Nomor 47/2013); 
6) Undang-Undang Republik Indonesia Nomor 18 Tahun 2009 tentang Peternakan dan Kesehatan Hewan; 7) Peraturan Menteri Pertanian Nomor 84/Permentan/PD.410/8/2013 tentang Impor Bangkai, Daging, Jeroan dan/ atau Derivatifnya ke dalam Wilayah Negara Republik Indonesia (Peraturan Menteri Pertanian Nomor 84/2013), yang mencabut dan menggantikan Peraturan Menteri Pertanian Nomor 50/Permentan/OT.140/9/2011 tentang Rekomendasi Persetujuan Impor Bangkai, Daging, Buangan yang Dapat Dimakan atau Hasil Olahannya ke Wilayah Indonesia (Peraturan Menteri Pertanian Nomor 50/2011) sebagaimana telah diubah dengan Peraturan Menteri Pertanian Nomor 63/Permentan/OT.140/5/2013 tentang Perubahan Atas Peraturan Menteri Pertanian Nomor 50/Permentan/OT.140/9/2011 tentang Persetujuan Impor Rekomendasi Bangkai, Daging, Jeroan, dan/ atau Derivatifnya ke dalam Wilayah Negara Republik Indonesia (Peraturan Menteri Pertanian Nomor 63/2013); 8) Peraturan Menteri Perdagangan Nomor 46/M-DAG/PER/8/2013 tentang Ketentuan Impor dan Ekspor Hewan dan Produk Hewan (Peraturan Menteri Perdagangan Nomor 46/2013), yang membatalkan dan menggantikan Peraturan Menteri Perdagangan Nomor 22/M-DAG/PER/5/2013 tentang Impor dan Ekspor Hewan dan Produk Hewan (Peraturan Menteri Perdagangan Nomor 22/2013) yang mencabut dan menggantikan Peraturan Menteri Perdagangan Nomor 24/M-DAG/ PER/9/2011 tentang Ketentuan Impor dan Ekspor Hewan dan Produk Hewan (Peraturan Menteri Perdagangan Nomor 24/2011); 9) UndangUndang Republik Indonesia Nomor 18/2012 tentang Pangan (UU Pangan); dan 10) Undang-Undang Republik Indonesia Nomor 19/2013 tentang Perlindungan dan Pemberdayaan Petani (UU Petani).

Instrumen hukum di atas, serta pelaksanaan aturannya tidak sesuai dengan kewajiban Indonesia berdasarkan ketentuan-ketentuan dari kesepakatan WTO yang tercakup pada pertama, Pasal III: 4 yang menjamin tentang diterapkannya prinsip national treatment. Kedua, Pasal X: 1 yang menyatakan bahwa undang-undang, peraturan, keputusan pengadilan dan keputusan administratif penerapan umum, dibuat efektif oleh pihak yang melakukan kontrak; yang berkaitan dengan klasifikasi atau penilaian produk untuk tujuan kepabeanan, atau tingkat kewajiban, pajak atau biaya lainnya, atau persyaratan, batasan atau larangan impor atau ekspor atau atas pengalihan pembayaran untuk itu, atau mempengaruhi penjualan, distribusi, transportasi, asuransi, inspeksi pergudangan, pameran, pemrosesan, pencampuran atau penggunaan lainnya, harus segera diterbitkan sedemikian rupa sehingga memungkinkan pemerintah dan pedagang untuk mendapatkan informasi yang dibutuhkan. Kesepakatan yang mempengaruhi kebijakan perdagangan internasional yang berlaku antara pemerintah atau lembaga pemerintah dari setiap pihak yang melakukan kontrak dengan pemerintah atau agen pemerintah dari pihak 
kontraktor lainnya juga harus dipublikasikan. Ketentuan dalam paragraf ini tidak mewajibkan pihak yang mengontrak untuk mengungkapkan informasi rahasia yang akan menghambat penegakan hukum atau bertentangan dengan kepentingan umum atau akan mengurangi kepentingan komersial yang sah dari perusahaan tertentu, publik atau swasta.

Terkait dengan Persetujuan Pertanian WTO, Indonesia melanggar Pasal 4.2 dari Persetujuan Pertanian yang menyatakan bahwa negara anggota tidak boleh menerapkan, menggunakan, atau kembali ke tindakan apa pun yang harus diubah menjadi hambatan dalam bentuk bea cukai biasa, kecuali jika diatur dalam Pasal 5 dan Lampiran 5.

Terkait Perjanjian Perizinan Impor, Indonesia dinilai melanggar Pasal 1.2 yang menyatakan bahwa negara anggota harus memastikan bahwa prosedur administrasi yang digunakan untuk menerapkan perizinan impor sesuai dengan ketentuan GATT 1994 yang relevan, termasuk lampiran dan protokolnya. Penafsiran perjanjian ini bermaksud untuk mencegah distorsi perdagangan yang mungkin timbul dari operasi yang tidak tepat dari prosedur tersebutdengan mempertimbangkan tujuan pembangunan ekonomi dan kebutuhan finansial dan perdagangan anggota negara berkembang. Pasal selanjutnya yang dilanggar adalah Pasal 1.5, 1.6, 2.2, dan 3,2 yang mengatur tentang aturan perizinan yang harus dibuat sesederhana mungkin, tidak menjadi beban atau menyulitkan secara administrasi, serta tidak dimaksudkan untuk batasan atau hambatan perdagangan. Pasal 3.3 mengatur tentang keharusan mempublikasikan informasi apabila suatu negara menerapkan batasan kuantitatif terhadap impor. Informasi tersebut meliputi dasar pemberian izin dan alokasi kepada negara mitra maupun pedagang. Pasal 5.1 mengatur bahwa negara harus mempublikasikan informasi terkait izin tersebut minimal 60 hari sebelum pemberlakuan. Pasal 5.2 menyebutkan detail data yang harus dimuat dalam informasi yang dipublikasikan.

Terkait dengan Perjanjian Inspeksi Pra-Pengiriman, Indonesia dinilai melanggar Pasal 2.1 yang mengatur tentang keharusan negara anggota untuk menerapkan prosedur inspeksi yang seragam terhadap semua negara anggota. Pasal 2.15 mengatur tentang keharusan negara anggota memastikan tidak ada penundaan inspeksi kecuali disepakati oleh kedua belah pihak untuk di-reschedule atau dalam kondisi force majeure.

Pembahasan pada bagian ini menunjukkan bahwa Indonesia melanggar beberapa kesepakatan WTO dalam aturan perdagangan hortikultura, hewan, dan produk hewan. Namun demikian, Indonesia menyatakan akan naik banding ke Appellate Body WTO setelah keputusan DSB yang menyatakan bahwa Indonesia melanggar. Indonesia diminta merubah aturannya agar sejalan dengan kesepakatan WTO dan 
menghilangkan hambatan perdagangan. Pada bagian selanjutnya akan dianalisa mengapa Indonesia mengajukan banding setelah kekalahannya.

\section{Analisa Kebijakan Develomental State Indonesia dalam Perdagangan Hortikultura, Hewan, dan Produk Hewan}

Pada bagian tinjauan hukum kasus sengketa perdagangan yang dibahas dalam tulisan ini, telah dipaparkan aturan-aturan Indonesia yang dinilai menghambat perdagangan dan merugikan negara lain. Telah dipaparkan juga kesepakatan-kesepakatan WTO yang tidak sesuai dengan aturan perdagangan Indonesia. Dengan demikian, dapat dilihat dasar dari penetapan laporan panel DSB yang memenangkan Selandia Baru dan Amerika Serikat atas Indonesia. Terkepas dari hal tersebut, Indonesia mengajukan banding ke Appellate Body untuk mempertahankan aturannya. Dalam tulisan ini, penulis menganalisa alasan Indonesia melakukan langkah tersebut menggunakan teori developmental state.

Pertama, developmental state berakar dari merkantilisme menekankan upaya negara untuk mendorong pertumbuhan ekonomi, produktivitas industri, dan daya saing global. Selain itu, negara juga mendorong produksi, bukan konsumsi. Kedua, negara aktif mengintervensi pasar. Pasar cenderung mengalami kegagalan sehingga harus diintervensi. Intervensi juga dilakukan untuk menghindari kompetisi eksesif. Ketiga, negara dianggap sebagai birokrasi yang rasional, pintar, dan kompeten (Johnson, 1998). Dalam kasus ini, asumsi tersebut dapat dilihat pada aturan pembatasan impor komoditas hortikultura, hewan, dan produk hewan.

Prinsip-prinsip developmental state dapat dilihat pada kerangka hukum yang menopang aturan impor untuk produk-produk hortikultura, hewan, dan produk hewan. Undang-undang tersebut beserta aturan pelengkapnya dijalankan berdasarkan premis bahwa impor produk-produk tersebut harus dilarang atau dikurangi ketika produksi dalam negeri dianggap cukup untuk memenuhi permintaan domestik. Sejak penerapan aturan-aturan ini, jumlah impor produk pertanian menurun drastis. Sebagai contoh, volume impor daging dari semua negara pada enam bulan pertama tahun 2015 hanya 34\% dari volume impor pada periode yang sama tahun 2000 (Global Trade Atlas, 2015). Penurunan volume impor global yang sama terjadi pada berbagai produk hortikultura dan peternakan. Kebijakan yang ditetapkan oleh Pemerintah Indonesia ini menggunakan dasar swasembada pangan sebagai justifikasi untuk mengontrol impor produkproduk pertanian dan peternakan.

Aturan-aturan perdagangan komoditas hortikultura, hewan, dan produk hewan yang sejalan dengan asumsi developmental state yang pertama adalah tentang kuota. Pasal 14 UU No. 18 Tahun 2012 tentang 
Pangan menyebutkan tentang impor dan mensyaratkan bahwa suplai pangan Indonesia berasal dari produksi pangan domestik dan cadangan pangan nasional serta apabila sumber-sumber tersebut tidak cukup, maka pangan yang dibutuhkan oleh masyarakat Indonesia dapat dipenuhi oleh impor sesuai dengan kebutuhan. Hal senada juga disebutkan dalam Pasal 36 (1) bahwa impor pangan hanya diperbolehkan jika produksi pangan domestik tidak mencukupi dan/atau tidak dapat diproduksi di dalam negeri. Undang-undang pangan menyatakan bahwa kecukupan pangan domestik ditentukan oleh menteri atau badan pemerintah yang bertugas pada bidang pangan.

Selanjutnya pada tahun 2013, Indonesia menerapkan UU No. 19 Tahun 2013 tentang Perlindungan dan Pemberdayaan Petani (UU Petani). Pasal 30 undang-undang tersebut menyebutkan bahwa setiap orang dilarang mengimpor komoditas pertanian ketika ketersediaan komoditas pertanian domestik cukup untuk konsumsi dan/atau cadangan pangan pemerintah. Undang-undang ini juga mengatur tentang hukuman kriminal sampai dua tahun penjara bagi yang melanggar.

Aturan yang sama juga diterapkan untuk komoditas hewan dan produk hewan. Melalui Pasal 36B (1) Amandemen UU Hewan memberi otoritas pada pemerintah untuk melarang impor sapi dan jeroan tanpa menyertakan rekomendasi dari Kementerian Pertanian. Impor tersebut dilarang karena pemerintah Indonesia menyatakan bahwa Indonesia sudah mampu untuk memenuhi permintaan komoditas tersebut dari produksi dalam negeri (Bisnis Indonesia, 2015). Berbagai peraturan tersebut digunakan pemerintah untuk melindungi petani (Pasal 3 UU Hortikultura), memberikan prioritas pada produksi lokal (Pasal 76 UU Hewan), memberikan prioritas pada penjualan produk lokal (Pasal 92 (1) UU Hortikultura), dan untuk mengontrol impor (Pasal 90 UU Hortikultura dan Pasal 56 UU Pangan).

Aturanselanjutnyayangsejalandenganprinsip-prinsipdevelopmental state adalah aturan-aturan mengenai prosedur perizinan impor. Untuk mengimpor komoditas hortikultura, hewan, dan produk hewan, importir harus mendapatkan izin dan persetujuan dari badan pemerintah sesuai dengan yang telah dipaparkan pada bagian pembahasan sebelumnya. Aturan tersebut menentukan desain, struktur, dan implementasi izin impor untuk produk-produk tersebut, terutama daging sapi dan jeroan. Pada kasus daging dan sapi hidup, Indonesia menyatakan untuk mengurangi impor sampai 10\% dari konsumsi total (Bab II(c)(3) Roadmap Swasembada Daging Kementerian Pertanian).

Prinsip developmental state selanjutnya dapat dilihat pada aturan distribusi impor untuk komoditas hortikultura, hewan, dan produk hewan. Indonesia melarang impor hewan dan produk hewan untuk penggunaan 
tertentu serta yang dijual dan didistribusikan pada toko-toko tertentu. Secara spesifik, daging sapi, jeroan yang diperbolehkan untuk diimpor (lidah dan ekor) dan bangkai hanya dapat diimpor ke Indonesia untuk digunakan oleh kalangan industri, restoran, katering, dan/atau kebutuhan khusus yang lain, serta hanya dapat didistribusikan atau dijual melalui saluran-saluran tersebut (Pasal 17, Aturan Menteri Pertanian No. 46/2013). Dengan demikian, produk-produk tersebut dilarang diimpor untuk dijual baik di retail modern maupun tradisional.

Di Indonesia, makanan dapat dibeli oleh konsumen di pasar modern (termasuk hypermarket, supermarket, dan toko-toko sejenisnya) atau tokotoko retail tradisional (termasuk pasar), warung, dan kaki lima. Dengan demikian, produk-produk daging dan jeroan impor yang sudah terbatas, tidak dapat dijual di toko-toko tersebut. Toko-toko retail tradisional memiliki proporsi yang tinggi pada penjualan pangan di Indonesia dan berdasarkan pada laporan tahun 2011, warung dan pasar masih mendominasi landscape retail di Indonesia (Razdan, 2013: 16). Pasar modern juga mewakili share penjualan retail pangan yang penting dan selalu berkembang di Indonesia (Razdan, 2013: 10) dengan estimasi share pasar untuk penjualan pangan antara 11\% dan 30\% (Suryadarma, 2007: 10). Mengingat ukuran yang signifikan dari sektor pasar ritel dan modern tradisional, melarang impor produk hewani sapi selain untuk digunakan di industri, hotel, katering, dan kebutuhan khusus lainnya (tidak termasuk penjualan melalui saluran ritel tradisional dan pasar modern) merupakan kendala parah pada kemampuan untuk mengimpor produk ini ke Indonesia.

Aturan distribusi pada penggunaan yang terbatas juga berlaku untuk komoditas hortikultura. Indonesia memberlakukan larangan dan pembatasan impor produk hortikultura yang terdaftar terkait dengan penggunaan, penjualan dan distribusinya. Pasal 15 Aturan Menteri Pertanian No. 16/2013 mengatur bahwa bisnis yang telah mendapat konfirmasi sebagai importir terdaftar hanya bisa memperdagangkan dan/atau mengalihkan produk hortikultura yang diimpor ke distributor dan dilarang melakukan perdagangan dan/atau mentransfer produk hortikultura yang diimpor langsung ke konsumen atau pengecer. Demikian juga Pasal 7 Aturan Menteri Perdagangan No. 16/2013 yang menyatakan bahwa bisnis yang telah menerima pengakuan sebagai produk PI-Hortikultura hanya dapat mengimpor produk hortikultura sebagai bahan baku atau sebagai bahan pelengkap untuk kebutuhan proses produksi industrinya dan dilarang melakukan perdagangan dan/atau mentransfer produk hortikultura tersebut.

Selanjutnya, prinsip developmental state dapat dilihat pada aturan syarat pembelian domestik. Sebelum mendapatkan rekomendasi dari Kementerian Pertanian, importir harus menunjukkan bahwa mereka 
telah membeli (menyerap) daging sapi yang cukup yang telah dipelihara dan disembelih di Indonesia. Persyaratan ini ditentukan dalam Pasal 5 Aturan Menteri pertanian No. 139/2014 yang menyatakan bahwa pertama: operator bisnis, Badan Usaha Milik Negara atau Badan Usaha Milik Daerah (sebagaimana dimaksud dalam Pasal 4) dalam mengimpor daging sapi harus menyerap daging sapi lokal dari rumah potong yang memiliki Nomor Pengawasan Veteriner. Kedua, penyerapan daging sapi lokal sebagaimana dimaksud pada ayat (1), harus diverifikasi oleh Dinas Provinsi dan/atau Kabupaten/Kota dari mana daging sapi lokal berasal.

Importir daging sapi (selain daging sapi yang diimpor untuk dimasukkan ke dalam proses manufaktur) harus menunjukkan bahwa setidaknya 3\% dari jumlah pembelian daging sapi berasal dari ternak yang dibesarkan dan disembelih di Indonesia. Sedangkan importir daging sapi untuk keperluan manufaktur harus menunjukkan bahwa setidaknya 1,5\% dari jumlah pembelian daging sapi berasal dari ternak yang dibesarkan dan disembelih di Indonesia.

Aturan mengenai harga referensi daging juga menunjukkan prinsipprinsip developmental state. Indonesia menerapkan sistem harga referensi untuk hewan ternak dan produk hewani. Aturan Menteri Perdagangan No. 46/2013 mengatur bahwa impor hewan ternak dan produk hewan dihentikan jika harga pasar daging sapi di Indonesia turun di bawah harga referensi acuan yang ditentukan. Harga referensi untuk daging sapi yang ditetapkan dalam Aturan Menteri Perdagangan No. 46/2013 adalah Rp. 76.000,00 per kilogram, namun hal ini dapat berubah sewaktu-waktu oleh Menteri Perdagangan setelah menerima saran dari Tim Pemantau Harga Daging Sapi.

Harga referensi daging sapi berdampak pada pelarangan impor produk hewan ternak dan sapi pada saat harga daging mentah di dalam negeri turun di bawah tingkat tertentu. Hal ini melindungi produsen daging sapi domestik dari persaingan dari daging sapi impor, dan menjaga harga daging sapi tetap tinggi.

Pada komoditas hortikultura, harga referensi juga ditetapkan pada cabai dan bawang merah. Impor cabai dan bawang merah dilarang apabila harga pasar dalam negeri turun di bawah harga referensi yang ditentukan. Harga referensi cabai dan bawang merah ditetapkan dalam dekrit Direktur Jenderal Perdagangan Dalam Negeri. Harga referensi dipantau oleh Tim Pemantau Harga Produk Hortikultura yang ditetapkan oleh Menteri Perdagangan.

Terakhir, prinsip-prinsip developmental state dapat dilihat pada aturan terkait periode panen. Indonesia melarang atau membatasi impor produk hortikultura tertentu selama masa panen di Indonesia. Sebagai bagian dari proses permohonan RIPH, importir diwajibkan untuk 
mengajukan rencana distribusi produk mereka serta menunjukkan waktu masuknya produk dan wilayah/kota tempat produk akan didistribusikan. Kementerian Pertanian memeriksa rencana distribusi terhadap periode panen untuk produk hortikultura dan membatasi jumlah yang diizinkan untuk diimpor sesuai dengan periode panen produk terkait. Aturan ini menunjukkan antara lain pertama, tidak ada impor bawang merah ketika panen besar di daerah panen utama di Indonesia. Kedua, tidak ada impor cabai apabila produksinya stabil sepanjang tahun. Ketiga, tidak ada impor mangga bila sebagian besar wilayah panen pada musim panen. Keempat, tidak ada impor pisang, melon, pepaya dan nanas ketika produksinya stabil sepanjang tahun dan mampu memenuhi permintaan domestik. Kelima, membatasi impor jeruk pada Oktober sampai Desember saja karena kawasan produksi utama jeruk di Indonesia akan panen pada bulan Juli dan Agustus.

Aturan-aturan tersebut senada dengan prinsip developmental state yang dinyatakan oleh Bolesta (2007) bahwa akibat ekonomi developmental state yang cenderung export-driven, maka negara-negara penganutnya harus mengikuti kondisi internasional dan memainkan posisi serta perannya pada ekonomi global. Hal tersebut yang dilakukan Indonesia dengan memainkan peran pada rezim perdagangan global untuk mempertahankan aturan yang memihak pada produk dalam negeri. Selanjutnya, aturanaturan tersebut juga dapat dilihat sebagai upaya untuk mempertahankan keamanan ekonomi sebagaimana prinsip developmental state yang dinyatakan oleh Dent. Menurut Dent, developmental state merupakan usaha untuk melindungi integritas struktural dan kemampuan mencapai kesejahteraan serta kepentingan entitas politik ekonomi dalam konteks berbagai resiko eksternal dan ancaman dihadapinya (Dent, 2003: 253). Terakhir, aturan-aturan tersebut sejalan dengan prinsip perlindungan sosial atas kerentanan terhadap keikutsertaan dalam liberalisme dan globalisasi yang dikemukakan oleh Weiss (2003). Atas pertimbangan tersebut, tulisan ini menilai bahwa Indonesia mengajukan banding ke Appellate Body WTO (terlepas dari temuan kesalahan berdasar tinjauan hukum di DSB) karena Indonesia menerapkan kebijakan developmental state dalam perdagangan komoditas hortikultura, hewan, dan produk hewan.

\section{Kesimpulan}

Indonesia telah menerapkan berbagai aturan perdagangan komoditas hortikultura, hewan, dan produk hewan yang dinilai menghambat perdagangan bebas sejak tahun 2011. Aturan-aturan tersebut merugikan Selandia Baru sebagai negara yang penghasilan besarnya berasal dari komoditas tersebut. Bersama Amerika Serikat yang menderita kerugian yang sama, Selandia Baru melaporkan pelanggaran tersebut 
ke DSB WTO. Berdasarkan tinjauan hukum, DSB menyatakan Indonesia bersalah dan diminta untuk menyesuaikan aturan perdagangannya dengan kesepakatan dan aturan WTO. Terlepas dari hal tersebut, Indonesia memilih mempertahankan aturannya dengan mengajukan banding ke Appellate Body. Hal tersebut dinilai karena Indonesia menerapkan kebijakan developmental state dalam perdagangan komoditas hortikultra, hewan, dan produk hewan. Prinsip-prinsip developmental state dapat dilihat pada aturan mengenai larangan impor, larangan penggunaan dan distribusi, serta perizinan yang mensyaratkan membeli produk domestik dalam persentase tertentu. Hal tersebut sesuai dengan prinsip-prinsip developmental state yang menekan impor, mendorong ekspor dan campur tangan pemerintah dalam ekonomi, memainkan peran di tatanan global untuk mencapai keamanan ekonomi domestik, dan perlindungan domestik dari kerentanan akibat keikutsertaan dalam globalisasi dan liberalisasi ekonomi.

\section{Daftar Pustaka}

Adolf, H. (2003). Hukum Ekonomi Internasional. Jakarta: Rajawali Pers.

Agustine, I. (2015). Dua jenis daging sapi ini tak boleh diimpor lagi: mengapa? [online]. Bisnis Indonesia. Tersedia di: <http://industri. bisnis.com/read/20150210/99/389184/dua-jenis-daging-sapi-ini-takboleh-diimpor-lagi.-mengapa.> [diakses 30 April 2017].

Bolesta, A. (2007). China as A Developmental State [online]. Montenegrin Journal of Economics No. 527 Juni. Tersedia di: <http://www.repec. mnje.com/mje/2007/v03-n05/mje_2007_v03-n05-a16.pdf.> [diakses 30 April 2017].

Chang, H.J. (1999). The Economic Theory of The Developmental State [online]. Isites Harvard University. Tersedia di: <http://isites.harvard. edu/fs/docs/icb.topic233853.files/March_10-12/Chang_Economic. pdf.> [diakses 30 April 2017].

Hermansyah, A. (2016). Indonesia to challenge trade dispute ruling favoring US, NZ [online]. The Jakarta Post. Tersedia di: <http://www. thejakartapost.com/news/2016/12/24/indonesia-to-challenge-tradedispute-ruling-favoring-us-nz.html.> [diakses 18 April 2017].

Johnson, C. (1982). MITI and the Japanese Miracle; the Growth of Industrial Policy 1925-1975. California: Stanford University Pr ess.

Johnson, C. (1999). The Developmental State: Odyssey of a Concept. Dalam Woo-Cumming, M. (ed.), The Developmental State. Ithaca: Cornell University Press.

Loriaux, M. (1999). The French Developmental State as Myth and Moral Ambition. Dalam Woo-Cummings, M. (ed.), The Developmental State. Ithaca: Cornell University Press.

Morrison, T. (2016). NZ, US win WTO case against Indonesia on trade 
restrictions [online]. Scoop Independent News. Tersedia di: $<$ http:// www.scoop.co.nz/stories/BU1612/S00890/nz-us-win-wto-caseagainst-indonesia-on-trade-restrictions.htm.> [diakses 18 April 2017].

New Zealand Foreign Affairs and Trade (2017). Current WTO Dispute [online]. New Zealand Foreign Affairs and Trade. Tersedia di: $<$ https:// www.mfat.govt.nz/en/trade/trade-law-and-dispute-settlement/ current-disputes/.> [diakses1 8 April 2017].

Razdan, R. et.al. (2013). The evolving Indonesian costumer [online]. McKinsey \& Company. Tersedia di: <http://www.mckinsey.com/ business-functions/marketing-and-sales/our-insights/the-evolvingindonesian-consumer $>$ [diakses18 Apri 1 2017].

Suryadarma, D. et.al. (2007). Impact of Supermarkets on Traditional Markets and Retailers in Indonesia's Urban Centers. Jakarta: Smeru Research Institute.

Truman, E.M. (Juni 1999). The Evolution of the International Financial System. Treasury Assistant Secretary for International Affairs Remarks at the Institute for International Monetary Affairs Eighth Symposiu m Tokyo, Japan.

Weiss, L. (2003). States in the Global Economy. Cambridge: Cambridge University Press.

Woo-Cumming, M. (ed). (1999). The Developmental State. Ithaca: Cornell University Press.

WTO (1994). Agreement on Agriculture [online]. World Trade Organization. Tersedia di: <https://www.wto.org/english/docs_e/legal_e/14ag_01_e.htm.> [diakses 8 Mei 2017].

WTO (1994). Agreement on Import Licensing Procedures [online]. World Trade Organization. Tersedia di: <https://www.wto.org/english/ docs_e/legal_e/23-lic.pdf.> [diakses 8 Mei 2017].

WTO (1994). Agreement on Pre-shipment Inspection [online]. World Trade Organization. Tersedia di: <https://www.wto.org/english/docs_e/ legal_e/21-psi_e.htm.> [diakses 8 Mei 2017].

WTO (1994). General Agreement on Tariffs and Trade [online]. World Trade Organization. Tersedia di: <https://www.wto.org/english/docs_e/ legal_e/gatt47_e.pdf.> [diakses 8 Mei 2017].

WTO (2014). Indonesia-Importation of Horticultural Products, Animals and Animal Products [online]. World Trade Organization. Tersedia di: <https://www.wto.org/english/tratop_e/dispu_e/cases_e/ds477_e. htm.> [diakses 8 Mei 2017].

WTO (2016). WTO Trade Statistical Review 2016 [online]. World Trade Organization. Tersedia di: <https://www.wto.org/english/res_e/ statis_e/wts2016_e/wts16_toc_e.htm.> [diakses 8 Mei 2017].

WTO (n.d.). Understanding the WTO [online]. World Trade Organization. 
Indonesian Perspective, Vol. 2, No. 1 (Januari-Juni 2017): 29-50

Tersedia di: <https://www.wto.org/english/thewto_e/whatis_e/tif_e/ tif_e.htm.> [diakses 8 Me i 2017]. 